\title{
Morphology and phylogenetic position of Spongiochrysis hawaiiensis gen. et sp. nov., the first known terrestrial member of the order Cladophorales (Ulvophyceae, Chlorophyta)
}

\author{
Correspondence \\ Fabio Rindi \\ fabio.rindi@nuigalway.ie
}

\author{
Fabio Rindi, ${ }^{1}$ Juan M. López-Bautista, ${ }^{2}$ Alison R. Sherwood ${ }^{3}$ \\ and Michael D. Guiry ${ }^{1}$ \\ ${ }^{1}$ Martin Ryan Institute, National University of Ireland, Galway, Ireland \\ ${ }^{2}$ Department of Biological Sciences, University of Alabama, PO Box 870345, Tuscaloosa, \\ AL 35487-0345, USA \\ ${ }^{3}$ Botany Department, 3190 Maile Way, University of Hawaii, Honolulu, HI 96822, USA
}

\begin{abstract}
Spongiochrysis hawaiiensis gen. et sp. nov. is described from material collected at two sites on O'ahu, Hawaiian Islands. This alga produced golden-yellow crusts on the bark of Casuarina trees and consisted of globular cells with an axial stellate chloroplast. The only form of reproduction was a specialized type of autosporulation in which a budding-like division of the mother cell produced daughter cells of different sizes. Phylogenetic analyses of the 18S rRNA gene showed that Spongiochrysis hawaiiensis is a member of the freshwater clade of the Cladophorales/ Siphonocladales lineage in the green algal class Ulvophyceae. On the basis of its unicellular habit and terrestrial habitat, this species is well differentiated from all other members of the same lineage and can be considered as the first known successful step of a member of the order Cladophorales into terrestrial habitats. The implications of the description of this species with regard to both green algal evolution and conservation of little-known tropical habitats are discussed. The holotype specimen of Spongiochrysis hawaiiensis is GALW015489 and isotype specimens have also been deposited in the BISH and BM herbaria.
\end{abstract}

\section{INTRODUCTION}

Subaerial microalgae are widespread in terrestrial ecosystems throughout the planet (Hoffmann, 1989; Nienow, 1996). Communities formed by these organisms produce coloured patches on a large number of natural and artificial substrata and their composition is known to vary greatly at several spatial and temporal scales. It is generally believed that eukaryotic algae are the principal element in subaerial algal communities of temperate regions, whereas cyanobacteria are quantitatively dominant in tropical regions (Fritsch, 1907). With relatively few exceptions, however, the subaerial algal floras of the tropics have not been studied as carefully as those of temperate zones. This is particularly true for certain regions, among which the Hawaiian Islands can be certainly included. Sherwood (2004) noted that the body of information concerning the non-marine algal flora of this

Abbreviations: Bl, Bayesian inference; MP, maximum-parsimony; NJ, neighbour-joining.

The GenBank/EMBL/DDBJ accession numbers for the 18S rRNA gene sequences of Spongiochrysis hawaiiensis sp. nov. are DQ077805 (population A) and DQ077806 (population B). archipelago, although dating from 1876 , is generally scarce. Records of terrestrial algae for the Hawaiian Islands are limited and are mostly based on occasional collections. Furthermore, identifications are frequently provided only at the genus level (Sherwood, 2004 and references therein).

Recently, the distribution and taxonomy of some groups of subaerial algae in this area was investigated, with particular regard to the genera Trentepohlia and Printzina (Rindi et al., 2005). In the course of the survey, an unexpected discovery was made. A bright golden-yellow coating was found on the bark of many trees on several beaches along the windward coast of O'ahu. These growths were initially thought to consist of species of the genera Trentepohlia or Printzina. Microscopic examination, however, revealed that they were produced by a unicellular green alga with a very unusual pattern of cell division. Production of new cells took place by a budding-like mechanism, which has so far been reported only for the genus Marvania (Hindák, 1976; Neustupa \& Šejnohová, 2003), a unicellular genus belonging to the class Trebouxiophyceae (Henley et al., 2004), and one species of Stichococcus, Stichococcus ampulliformis Handa (Handa et al., 2003). Our alga, however, differed from these entities 
in regard to the habit of the chloroplast and other morphological features. It became clear immediately that this alga was an undescribed entity of uncertain phylogenetic affinities.

In the last 20 years, the phylogeny of the green algae has been intensively investigated by molecular methods and this has led to the establishment of two major evolutionary lineages (Friedl, 1997; Chapman et al., 1999; Lewis \& McCourt, 2004). The charophyte lineage, or Streptophyta, comprises a relatively limited number of species (mostly freshwater and terrestrial) and also includes the embryophytes or land plants. The chlorophyte lineage, which includes the vast majority of described green algae, consists of four main classes, the Chlorophyceae, Trebouxiophyceae, Ulvophyceae and Prasinophyceae. At present, the majority of terrestrial green algae is included in the class Trebouxiophyceae and class Klebsormidiophyceae of the charophyte lineage. It is now generally accepted that gross morphology and reproductive features do not reflect phylogenetic patterns in many groups of green algae, both in the charophyte lineage (McCourt et al., 2000; Gontcharov et al., 2003) and in the chlorophyte lineage (Tan et al., 1999; Famá et al., 2002; Krienitz et al., 2003; Fawley et al., 2004; Henley et al., 2004; Krienitz et al., 2004; O'Kelly et al., 2004). In several common groups of terrestrial algae, taxonomic entities with very similar morphologies have been proven to be only distantly related from a phylogenetic point of view and to represent examples of morphological convergence (Krienitz et al., 2004). An analysis of sequences of the small-subunit of rRNA (18S rRNA gene) showed that this was also the case for the novel alga from O'ahu. 18S rRNA gene sequences, which were obtained for two populations of the novel alga, showed unequivocally that this alga is not related to either the genera Marvania or Stichococcus and is a member of the Cladophorales/Siphonocladales lineage of the green algal class Ulvophyceae. To date, this group has only been known to include marine and freshwater species with more or less complex multicellular thalli and so the discovery of the novel alga is of exceptional interest and should shed new light on the evolution of this algal group. In this paper, we report in detail on the morphology and phylogenetic position of this novel alga. The novel alga is described as Spongiochrysis hawaiiensis gen. et sp. nov. and the evolutionary implications of its discovery are discussed in detail.

\section{METHODS}

Collection and examination of samples. Collections of the novel alga were made on six occasions from two sites on O'ahu, Hawaiian Islands (Kailua Beach Park, 24 September 2002, 8 July 2004 and 9 June 2005; Waimanalo Beach Park, 27 March 2004, 11 July 2004 and 9 June 2005). For each collection, fragments of bark covered by a golden-yellow crust were removed from several Casuarina trees. Limited observations in culture were made by placing the alga in liquid Jaworski's medium at 20 and $25^{\circ} \mathrm{C}, 16: 8 \mathrm{~h}$ light: dark cycle, $20-30 \mu \mathrm{mol}$ photons $\mathrm{m}^{-2} \mathrm{~s}^{-1}$. Plastic dishes containing approximately $30 \mathrm{ml}$ medium were used. The alga grew slowly and isolation into unialgal cultures was not possible.
For both field collections and cultured material, detailed examinations were carried out by light microscopy and microphotographs were taken with a digital camera (DXM1200; Nikon). Abbreviations for herbaria follow Holmgren et al. (1990).

DNA extraction. Material collected at Kailua Beach Park (population A) and Waimanalo Beach Park (population B) in July 2004 was used for DNA extraction and amplification of the 18S rRNA gene. Samples were preserved in silica gel in airtight bags. Cells were disrupted by grinding with a sterile pestle and mortar. DNA was extracted using the DNeasy plant mini kit (Qiagen) according to the manufacturer's instructions. DNA samples were stored at $-20{ }^{\circ} \mathrm{C}$. The integrity of the DNA preparations was checked by electrophoresis in agarose gels stained with ethidium bromide.

PCR amplification and sequencing. DNA was amplified by PCR of the nuclear-encoded 18S rRNA gene using primers designed for both green algae and plants (Hamby et al., 1988). DNA templates were amplified in $0.2 \mathrm{ml}$ thin-walled PCR tubes, in a total reaction volume of $10 \mu \mathrm{l}$. Each reaction consisted of $1 \cdot 25 \mu \mathrm{l}$ each GeneAmp deoxynucleotide mixture (containing dATP, dTTP, dCTP and dGTP), $\mathrm{MgCl}_{2}$ (25 mM; Perkin Elmer) and $10 \times$ buffer (Perkin Elmer), $0 \cdot 1 \mu \mathrm{l}$ Taq DNA polymerase (New England Biolabs), $0 \cdot 62 \mu \mathrm{l}$ each flanking primer, $2 \cdot 5 \mu \mathrm{l} 5 \mathrm{M}$ betaine (Sigma) and sterile water. Reactants and plastic ware were exposed to UV light in a PCR workstation for a period of $20 \mathrm{~min}$ to avoid contamination before $1 \mu \mathrm{l}$ template DNA was added. Negative controls without DNA template were included. Amplification was carried out in a GeneAmp PCR Thermal Cycler 2700 (Applied BioSystems) with an initial denaturation step of $96^{\circ} \mathrm{C}$ for $10 \mathrm{~s}$, followed by 40 cycles of $1 \mathrm{~min}$ at $94^{\circ} \mathrm{C}$, primer annealing for $1 \mathrm{~min}$ at $50^{\circ} \mathrm{C}$ and extension for $1.5 \mathrm{~min}$ at $72{ }^{\circ} \mathrm{C}$. Total amplified products and a standard 100 bp DNA ladder (New England BioLabs) were visualized by electrophoresis on a $0 \cdot 6 \%$ agarose gel (ICN Biomedicals) stained with ethidium bromide and examined for correct length, yield and purity. PCR products were excised from the gel with a sterile razor blade and transferred to a $0.5 \mathrm{ml}$ centrifuge tube. The products were concentrated and purified with the MinElute gel extraction kit (Qiagen) following the manufacturer's protocol. Purified DNA amplification products were checked for concentration with a NanoDrop ND-1000 spectrophotometer and sequenced with internal $18 \mathrm{~S}$ rRNA primers using the protocol for the DNA sequencing kit (ABI Prism Big-Dye terminator cycle sequencing ready reaction; Applied BioSystems). Sequencing reactions were purified in Sephadex G-50 fine columns (Amersham Biosciences) and sequenced in an ABI 3100 automated sequencer. DNA sequences were captured both as text and as colour-coded electropherograms.

Sequence alignment and phylogenetic analyses. Sequence data were edited and aligned using SEQUENCHER 4.5 (Gene Codes Corporation). The alignments used for the analyses are deposited in the EMBL-Align database (http://www.ebi.ac.uk/embl/Submission/ align_top.html). Edited sequences were manually adjusted using MacClade 4.06 (Maddison \& Maddison, 2001). Phylogenetic reconstruction based on the $18 \mathrm{~S}$ rRNA gene sequence database was performed using PAUP ${ }^{*} 4.0 \mathrm{~b} 10$ for Macintosh (Swofford, 2000) and MRBAYES 3.0 (Huelsenbeck \& Ronquist, 2001). Computer analyses were implemented with the distance (neighbour-joining, NJ), maximum-parsimony (MP) and Bayesian inference (BI) methods for phylogenetic reconstruction. Bootstrap analyses were performed to assess the stability/support of nodes with 1000 replications for $\mathrm{NJ}$ and MP. A total of 55 green plants was used to construct the data matrix. A subset of 51 taxa of Viridiplantae with two glaucocystophyte taxa as the outgroup was used to position the genus Spongiochrysis in the global phylogeny of green plants. Another subset containing 45 taxa from the Siphonocladales/Cladophorales complex was used to evaluate the position of the genus Spongiochrysis within this complex. Model parameters used in the inference 
methods to reconstruct phylogenies were estimated with MODELTEST 3.6 (Posada \& Crandall, 1998). Distance and MP analyses were performed with PAUP* 4.0. MP analyses were performed with the heuristic search option with a branch-swapping algorithm (tree bisection-reconnection) and random 1000 addition-sequence replicates. Bootstrap analyses (Felsenstein, 1985) were used to assess the stability/support of nodes with 1000 replicates. MRBAYES 3.0 was used in order to estimate the posterior probabilities for BI topologies. One million generations were run under BI analysis, trees were sampled every 100 and the earliest 4000 trees (burnt) were discarded followed by a computation of a consensus tree in PAUP* 4.0 .

\section{RESULTS}

\section{Latin diagnosis of Spongiochrysis Rindi, López-Bautista, Sherwood et Guiry, gen. nov.}

Cellulae solitariae vel binae, in statu post divisionem coniunctae, in cortice arborum viventes. Cellulae rotundae vel ovales. Chloroplastus unicus, centralis, stellatus. Flagella nulla. Reproductio asexualis, protoplasti divisione in partes duas; in initiali divisione cellulae filiae similes videntur, deinceps dimensione differentes. Reproductio sexualis ignota.

\section{Description of Spongiochrysis gen. nov.}

Spongiochrysis (Spon.gi'o.chry.sis. L. adj. spongius spongy; Gr. fem. n. chrysis a piece of gold plate; N.L. fem. n. Spongiochrysis derived from the habit of the type species, which forms a golden yellow layer with the texture of a sponge, hard when dry and soft when wet).

Cells solitary or in pairs, joined after division and living on the bark of trees. Cells rounded or oval. Chloroplast single, axial and stellate. Flagella absent. Asexual reproduction by division of the protoplast into two parts; in the first division the daughter cells appear similar in size, in subsequent divisions, they are different. Sexual reproduction unknown. Type species: Spongiochrysis hawaiiensis Rindi, LópezBautista, Sherwood and Guiry.

\section{Latin diagnosis of Spongiochrysis hawaiiensis sp. nov. (Fig. 1)}

Cellulae rotundae vel ovales, 10-20 $\mu \mathrm{m}$ latae; colour rubrum, luteum vel viride. Membrana cellulae crassa, plurimis stratis formata. Habitat in cortice arborum in Hawaiianis Insulis.

\section{Description of Spongiochrysis hawaiiensis sp. nov.}

Spongiochrysis hawaiiensis (ha.wai'i.en.sis. N.L. fem. adj. hawaiiensis pertaining to Hawaii, where the alga was originally found).

Cells rounded or oval, $10-20 \mu \mathrm{m}$ in diameter; colour is red, orange or green. Cell wall is thick and formed by several layers. Lives on tree bark in the Hawaiian Islands.

Holotype specimen: GALW015489. Material forming a yellow layer on a fragment of bark of Casuarina equisetifolia
Linnaeus, collected by A. R. Sherwood at Waimanalo Beach, O’ahu, Hawaiian Islands, on 11 July 2004.

Isotype specimens deposited in BISH and BM.

Type locality: Waimanalo Beach Park, O'ahu, Hawaiian Islands, USA.

\section{Distribution and ecology}

Spongiochrysis hawaiiensis formed a bright golden-yellow, thick crust on the bark of many trees of Casuarina equisetifolia at Kailua and Wainamalo Beach Parks, as well as many other locations along the windward coast of O'ahu. When dry, the crusts had a very hard and compact texture; when wet, however, they became soft and powdery. Although collections were not made on a regular basis, yellow-orange coatings of Spongiochrysis hawaiiensis were widespread at the two sites at the time of each visit and populations of this species appear to be perennial.

\section{Vegetative and reproductive morphology}

Cells of Spongiochrysis hawaiiensis were globular, 10-20 $\mu \mathrm{m}$ in diameter (Fig. 1a, b). Each cell contained a single chloroplast, which was primarily axial and stellate, with many irregular protrusions arising from the centre (Fig. 1a, c); its habit and colour, however, showed some variation in relation to environmental conditions. The colour varied from intense red-orange to light-green. In cells directly exposed to light, the production of a red-orange pigment (seemingly associated with the chloroplast) was stimulated. In old, dying cells, the pigment tended to be condensed in a few large droplets. Conversely, in cells not directly exposed to light, the pigment was not produced or occurred only in limited amounts and the cells appeared light-green. In cells growing in mixed cultures, the shape of the chloroplast underwent substantial changes. The central part of the chloroplast became hollow and, in most cases, extended peripherally by the development of the protrusions. In some cases, the protrusions appeared to become separated from the original body of the chloroplast. As result of this development, in most cells, the chloroplast became parietal and showed an irregularly reticulate appearance (Fig. 1d, e). No pyrenoids could be observed at any stage, although their presence in the field material could have possibly been obscured by the pigment.

Reproduction was by autosporulation, which took place by a budding-like division of the mother cell. The mother cell produced a cytoplasmic protuberance into which part of the cell contents was transferred (Fig. 1d, f). Following mitosis and cytokinesis, two daughter cells were separated by rupture of the mother cell wall at the level of the septum (Fig. 1c, f). In the first division, the protuberance reached approximately the same dimension as the original cell and the two daughter cells released were approximately the same size (Fig. 1b). One of the two daughter cells, however, remained entrapped in the wall of the original mother cell. This cell grew and produced a new protuberance of a smaller 


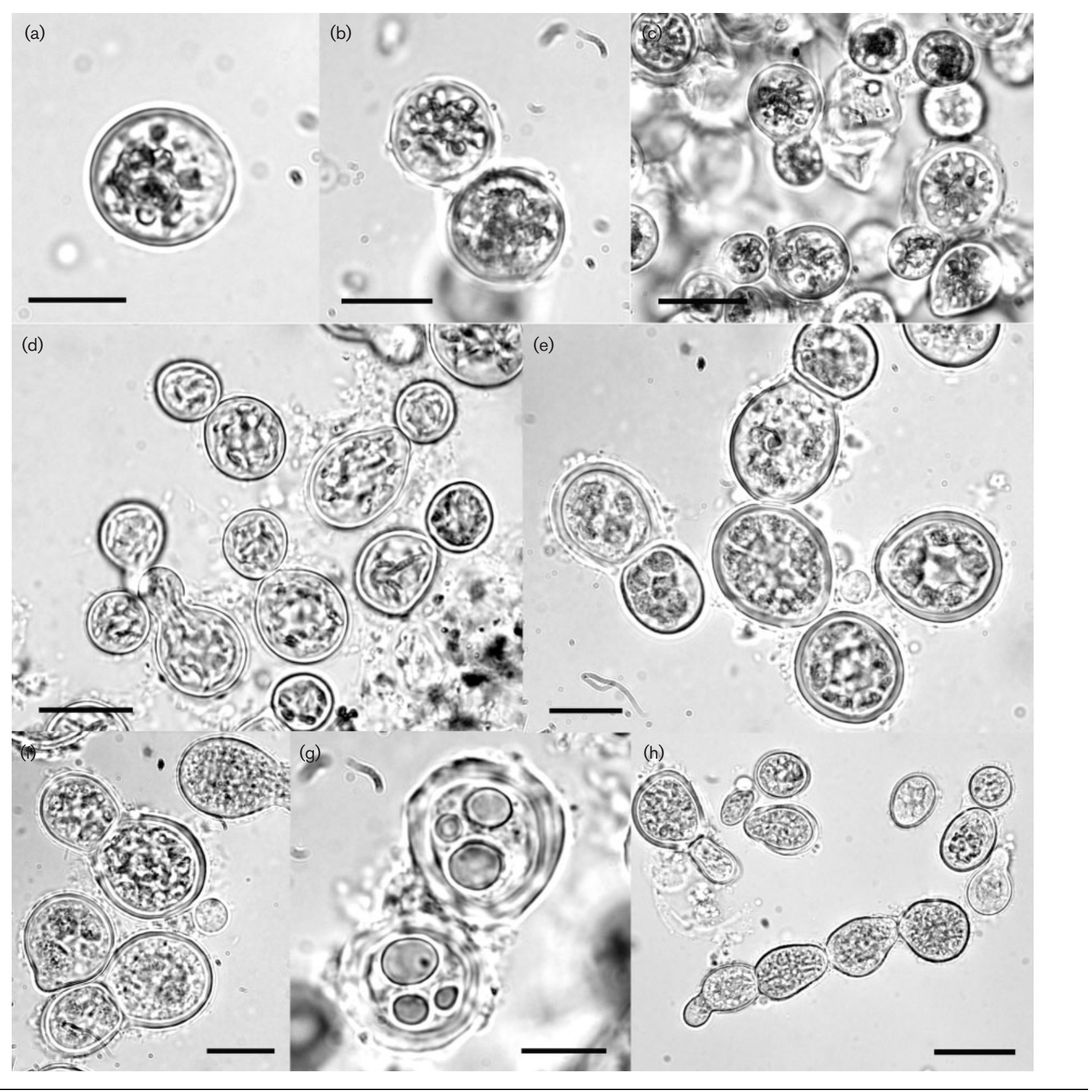

Fig. 1. Light microscope images of Spongiochrysis hawaiiensis sp. nov. (a) Detail of an individual cell. (b) Two cells arising from division of a common mother cell; note the axial, stellate chloroplast. (c) Detail of field material. (d, e) Material growing in mixed culture; note chloroplasts becoming parietal. (f) Detail of some cells at different stages of division. (g) Detail of two old cells; note cell wall formed by multiple layers and pigment condensed in a few, large droplets. (h) Detail of some cells producing pseudofilamentous forms. Bars: (a, b) $10 \mu \mathrm{m}$; (c) $20 \mu \mathrm{m}$; (d) $15 \mu \mathrm{m}$; (e, f, g) $10 \mu \mathrm{m}$; (h) $20 \mu \mathrm{m}$.

size by the same mechanism. This then grew to protrude through the portion of cell wall that was ruptured during the first division. A new division took place at the level of the septum and produced two daughter cells of different sizes. The cell enclosed in the original cell wall produced a new layer of cell wall material and was markedly larger than the cell derived from the separation of the protrusion. A cell retained in the wall of the original mother cell could divide up to three times by this mechanism; this was shown by the occurrence of up to three layers of cell wall (Fig. 1g). No walls with more than three layers were observed and it is presumed that, at this stage, the contents of the cell either died or were extruded out of the wall. Most globular cells that did not show protrusions were $14-16 \mu \mathrm{m}$ in diameter. Young daughter cells that had just separated as smaller protrusions were $10-13 \mu \mathrm{m}$ in diameter. Old cells, enclosed 
in multiple layers of cell wall, were $16-20 \mu \mathrm{m}$ in diameter. The production of short pseudofilamentous stages, determined by the fast division of several daughter cells, was observed occasionally (Fig. 1h). No other forms of reproduction were observed.

\section{Phylogeny}

In order to reconstruct the overall position of Spongiochrysis hawaiiensis in an 18S rRNA gene phylogeny of the green plant lineages, an analysis was performed with 51 taxa and 1732 equally weighted, aligned characters. Except for the two populations of Spongiochrysis hawaiiensis, all other sequences were downloaded from GenBank as established in López-Bautista \& Chapman (2003). Two glaucocystophytes (Cyanoptyche gloeocystis Pascher and Glaucocystis notochinearum Itzigsohn) were included as an outgroup. All the major groups of the kingdom Viridiplantae were represented in the analysis (Fig. 2), including representatives of the streptophyte lineage (charophyceans and Embryophyta) and the chlorophyte lineage. In all NJ, MP and BI analyses, Spongiochrysis hawaiiensis was positioned unequivocally within the chlorophytan lineage. The two samples of Spongiochrysis hawaiiensis were found nested in the ulvophycean clade with good nodal support $(87 / 72 / 1 \cdot 0)$ in all inference methods used. This phylogenetic tree also shows that Spongiochrysis hawaiiensis is a strongly supported clade $(100 / 100 / 1 \cdot 0)$ within the Siphonocladales/Cladophorales complex.

Based on the results described above, a more restricted analysis was performed in order to elucidate the precise position of the genus Spongiochrysis inside the Cladophorales/Siphonocladales clade. For this purpose, a subset of 41 taxa was evaluated with 1595 equally weighted characters (Fig. 3). Two ulvophycean taxa were used as the outgroup [Ulva rigida C. Agardh and Ulothrix zonata (Weber et Mohr) Kützing]. In all reconstruction analyses, including NJ, MP and BI, the genus Spongiochrysis was unequivocally nested within the Aegagropila clade (as defined by Hanyuda et al., 2002). This alliance was very well supported by bootstrap proportions and posterior probabilities $(100 / 96 / 1 \cdot 0)$. Although the position of Cladophora conchopheria Sakai inside this group was unstable under NJ and MP, the BI analysis showed Cladophora conchopheria as a basal clade to the Aegagropila clade (data not shown) and the genus Spongiochrysis in an intermediate position followed by the rest of the representatives of this group.

\section{DISCUSSION}

\section{Morphology and reproduction}

The unusual mechanism of cell division observed in Spongiochrysis hawaiiensis is the most peculiar aspect of the biology of this novel alga. The budding-like autosporulation readily separates this species from the large majority of unicellular green algae, in which reproduction normally takes place by binary fission or various forms of sporulation, with the production of either sessile autospores or motile zoospores (Ettl \& Gärtner, 1995; Van den Hoek et al., 1995). To date, this unusual type of cell division has been reported for members of only two genera of green algae, both belonging to the Trebouxiophyceae: the genus Marvania Hindák 1976 and the genus Stichococcus Nägeli 1849.

The genus Marvania was proposed by Hindák (1976) for Marvania geminata, a small unicellular alga isolated from the phytoplankton of a water reservoir at Petrova Ves and the river Morava at Bratislava, Slovakia. The budding-like mechanism of cell division was the main character on which Hindák (1976) based the new genus and which separated it from similar genera (Stichococcus and Hortobagyiella Hajdu 1975). Subsequently, Reymond et al. (1986) and Sluiman \& Reymond (1987) examined the mechanism of division using transmission electron microscopy and showed that it can be considered to be a highly modified form of autosporulation. By analysis of $18 \mathrm{~S}$ rRNA gene sequences, Henley et al. (2004) elucidated the phylogenetic position of M. geminata, showing that the position of the genus Marvania in the trebouxiophycean lineage is very well supported. Recently, Neustupa \& Šejnohová (2003) described a third species of Marvania, Marvania aerophytica, from subaerial habitats (the bark of Pandanus trees in secondary rainforest at Hulu Kelantan, Malaysia). More or less simultaneously, Handa et al. (2003) recorded a unicellular alga with the buddinglike division typical of members of the genus Marvania from bark of Cephalotaxus harringtonia (Knight ex Forbes) K. Koch at Taishaku-kyo Gorge, Japan. From the common habitat type and the descriptions of Neustupa \& Šejnohová (2003) and Handa et al. (2003), it seems likely that the algae reported separately by these authors are, in fact, the same species. Handa et al. (2003) sequenced about two-thirds of the $18 \mathrm{~S}$ rRNA gene and found this alga to be strictly related to Stichococcus bacillaris Nägeli (the type species of the genus Stichococcus) and species of the genus Prasiola (a blade-like genus of the family Prasiolaceae; Sherwood et al., 2000; Rindi et al., 2004). On this basis, they described the alga as a novel species and named it Stichococcus ampulliformis Handa. The number of species of the Stichococcus-Prasiola clade included in the analysis of Handa et al. (2003) was relatively limited and, in our opinion, it is likely that further analyses based on a larger number of taxa will result in rearrangements of the position of this alga at the species and genus level. When combined, however, the results of Handa et al. (2003) and Henley et al. (2004) indicate that M. geminata and Stichococcus ampulliformis/M. aerophytica are unrelated entities, clearly separated at the genus (and probably family) level.

An important implication of this is that the budding-like autosporulation typical of members of the genus Marvania has arisen separately at least three times in the evolution of the green algae. This happened not only in different genera of the class Trebouxiophyceae (the genera Marvania 


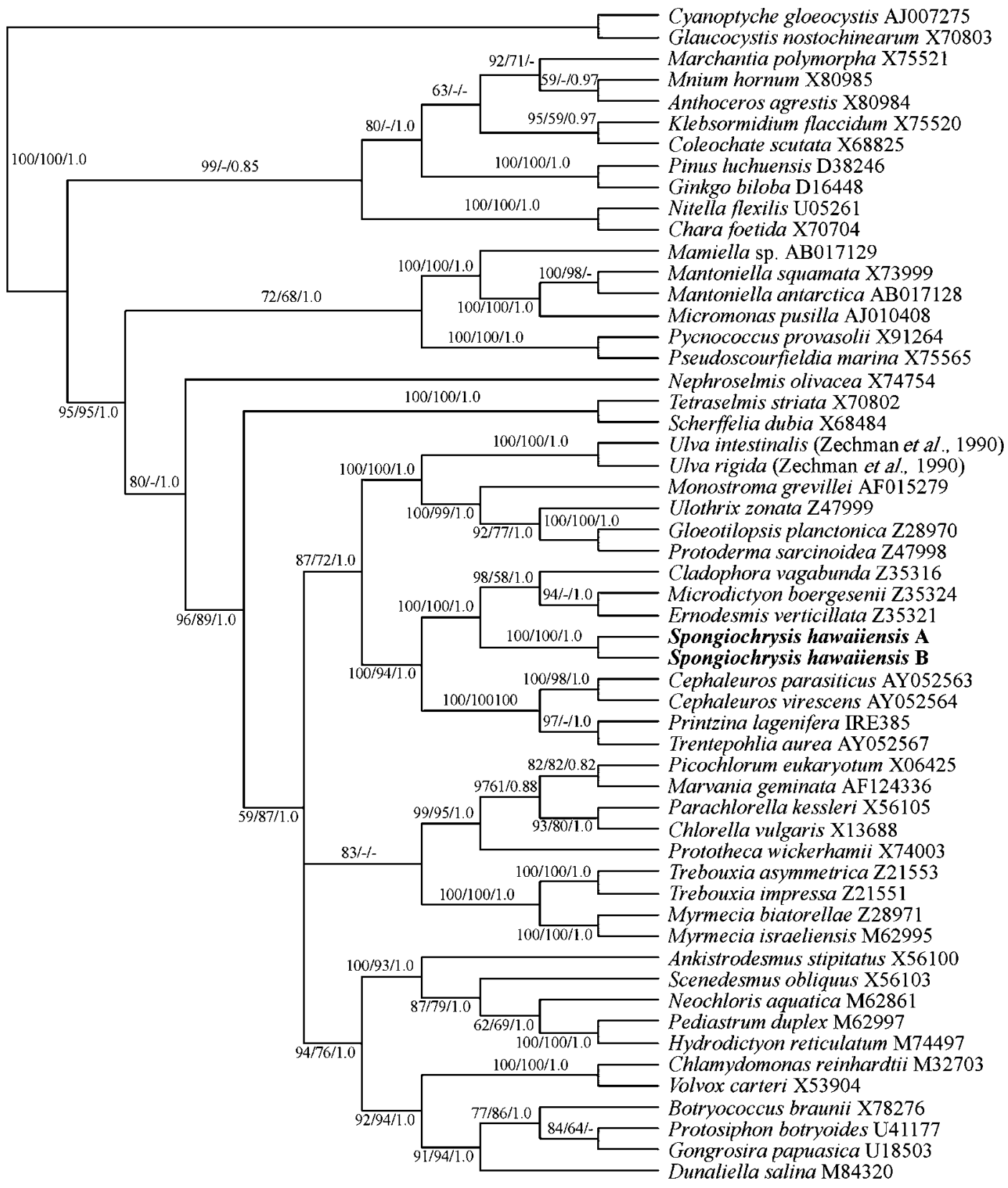

Fig. 2. Cladogram for an $18 \mathrm{~S}$ rRNA gene sequence alignment of 1732 characters with 55 representatives of the Viridiplantae and Spongiochrysis hawaiiensis. Support values above the branches are NJ bootstrap, MP bootstrap and BI posterior probabilities (from left to right). Base frequencies, $A=0 \cdot 2408, C=0 \cdot 2186, G=0 \cdot 2762$ and $T=0 \cdot 2644$. The model selected is $\operatorname{TrN}+\mathrm{I}+\mathrm{G}$ with proportion of invariable sites $(I)=0.4135$ and a gamma distribution shape parameter of 0.5868 .

and Stichococcus), but also in two different classes, the Trebouxiophyceae and the Ulvophyceae. The mechanism of cell division in Spongiochrysis hawaiiensis is identical to that of M. geminata, as carefully described by Reymond et al. (1986). Our phylogenetic analysis, however, shows that the inclusion of Spongiochrysis hawaiiensis in the class Ulvophyceae is beyond any doubt. Spongiochrysis hawaiiensis is also separated from species of the genus Marvania and from Stichococcus ampulliformis by other morphological features. The shape of the chloroplast in Spongiochrysis hawaiiensis has been shown to vary from axial stellate to reticulate parietal. Parietal cup-shaped chloroplasts, as reported for M. geminata and Stichococcus ampulliformis/ M. aerophytica (Hindák, 1976; Handa et al., 2003; Neustupa \& Šejnohová, 2003), have never been observed in Spongiochrysis hawaiiensis under any circumstances. Although a detailed biochemical characterization has not been possible, microscopic observations suggest that the red-orange 


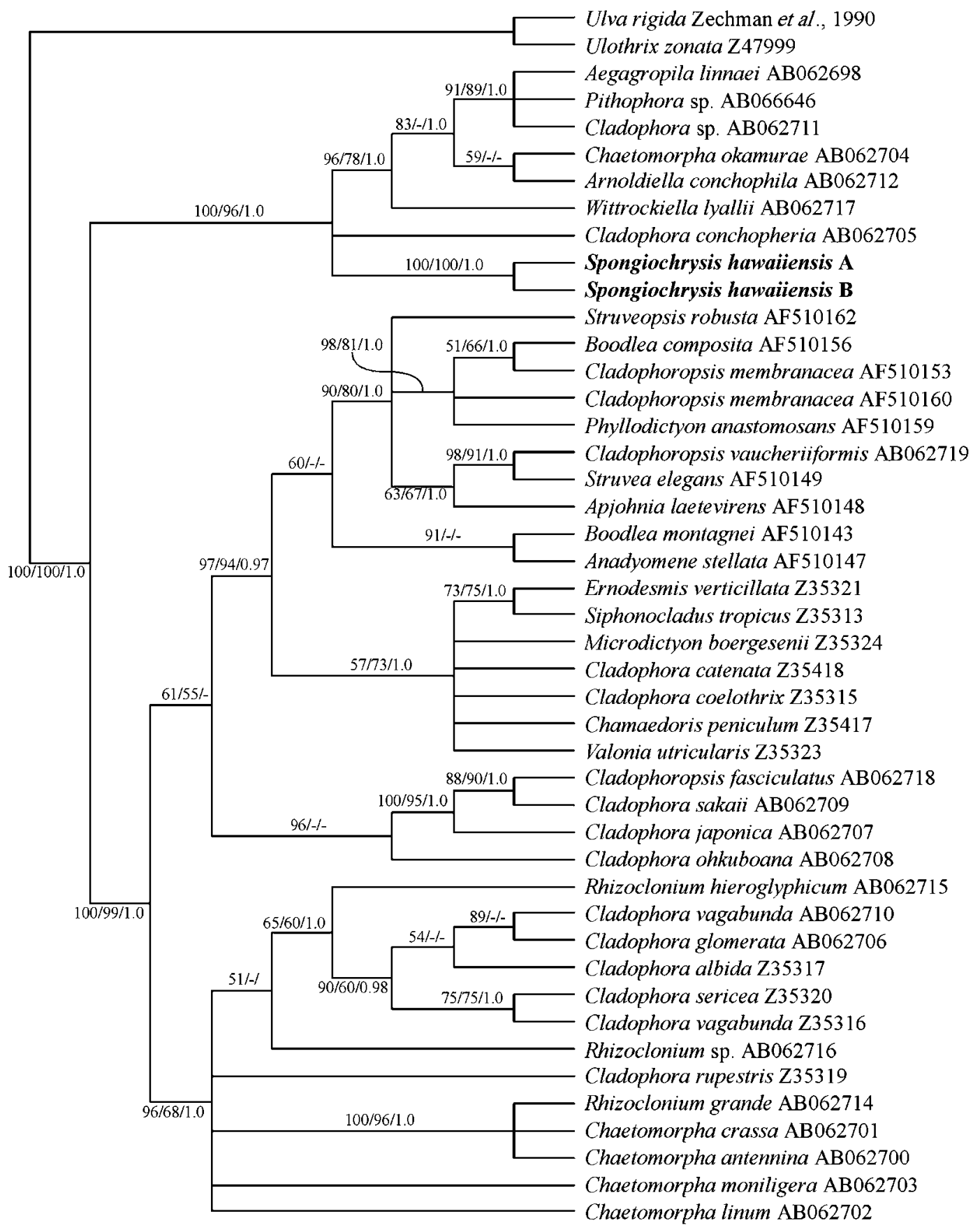

Fig. 3. Cladogram for an $18 \mathrm{~S}$ rRNA gene sequence alignment of 1595 characters with 41 representatives of the Siphonocladales/Cladophorales complex, two outgroup taxa and Spongiochrysis hawaiiensis. Support values above the branches are NJ bootstrap, MP bootstrap and $\mathrm{BI}$ posterior probabilities (from left to right). Base frequencies, $A=0 \cdot 2404$, $\mathrm{C}=0.2159, \mathrm{G}=0.2823$ and $\mathrm{T}=0.2614$. The model selected is $\mathrm{GTR}+\mathrm{I}+\mathrm{G}$ with proportion of invariable sites $(\mathrm{I})=0.5584$ and a gamma distribution shape parameter of $0 \cdot 4740$.

colour of healthy field-collected cells of Spongiochrysis hawaiiensis is due to a carotenoid pigment. The presence of such pigment has not been reported for either M. geminata or Stichococcus ampulliformis, although production of oil droplets is mentioned for both species (Hindák, 1976;
Handa et al., 2003; Neustupa \& Šejnohová, 2003). Furthermore, the cell wall of $M$. geminata is frequently characterized by granular or rib-like ornamentations (Hindák, 1976) which were not observed in Spongiochrysis hawaiiensis. 


\section{Phylogenetic considerations}

The discovery of Spongiochrysis hawaiiensis has considerable implications for the phylogeny of the green algae, and, in particular, for the Cladophorales/Siphonocladales lineage of the class Ulvophyceae. Photosynthetic life in terrestrial environments has derived from aquatic forms through multiple invasions. From an ecological point of view, the single most important conquest of the land was that of the green algae, which gave rise to the land plants and prepared the way for the colonization of the land by terrestrial life as we know it. However, several other lineages of green algae did succeed in developing a permanent existence in terrestrial habitats, even though they conserved a much simpler thallus that was morphologically similar to that of their aquatic ancestors. Today, all main groups of green algae, both in the chlorophyte lineage and in the charophyte lineage, include at least some terrestrial or semi-aquatic members. The class Ulvophyceae is formed primarily by the vast majority of marine green algae. It also includes a limited number of freshwater forms and, so far, the order Trentepohliales has been the only terrestrial group known for this class (López-Bautista \& Chapman, 2003). Spongiochrysis hawaiiensis therefore represents the second known successful colonization of terrestrial environments in the class Ulvophyceae and adds a new lineage to the series of conquests of land that took place separately in the green algae.

This discovery is even more important as Spongiochrysis hawaiiensis sp. nov. is shown unambiguously to belong to the Cladophorales/Siphonocladales lineage, a group for which no terrestrial members have been known to date. This group includes 32 genera with a relatively wide range of thallus morphology (branched or unbranched filaments, pseudoparenchymatous thalli, stipitate plants, blade-like thalli and reticulate plants composed of anastomosing filaments) and its circumscription at the order and class level has long been unclear. In older systems of classification, algae belonging to this group have usually been separated into two different orders, the Cladophorales and the Siphonocladales, mainly on the basis of differences in thallus architecture. Less frequently, they have been placed in a single order Siphonocladales sensu lato (see Leliaert et al., 2003, for further details on the nomenclatural and taxonomic history of the group). The molecular datasets currently available confirm the close relationship between species attributed to the Cladophorales and species attributed to the Siphonocladales, but also show that several genera, as traditionally circumscribed, are polyphyletic (Kooistra et al., 1993; Bakker et al., 1994; Hanyuda et al., 2002; Leliaert et al., 2003). In any case, whatever delimitation may be adopted at higher taxonomic levels, it is clear that the Cladophorales/ Siphonocladales form a coherent monophyletic lineage which includes mostly marine organisms. In this lineage, the subaerial habitat, unicellular habit and the mode of cell division of Spongiochrysis hawaiiensis are unique and separate this novel alga from all other members, justifying the erection of a new genus.
From an evolutionary point of view, the basal position of Spongiochrysis hawaiiensis in the Aegagropila group (as defined by Hanyuda et al., 2002) is particularly interesting. Species forming this clade belong to several genera (the genera Aegagropila, Arnoldiella, Chaetomorpha, Cladophora, Pithophora and Wittrockiella) and, with only a few exceptions, they are distributed in freshwater habitats (in which they differ strikingly from all other representatives of the Cladophorales/Siphonocladales, which are principally marine). It is also noteworthy that the habitats of the only two marine forms sequenced by Hanyuda et al. (2002), Wittrockiella lyallii (Harvey) Hoek and Cladophora conchopheria Sakai, are not typically marine. Wittrockiella lyallii, included in the analysis of Hanyuda et al. (2002), was collected from fjords with lowered salinity. Cladophora conchopheria is a reduced species of the genus Cladophora that grows on the shells of the snail Lunella coronata Gmelin in the upper intertidal zone (Sakai, 1964; Hanyuda et al., 2002). These algae are adapted to tolerate salinity variation and their habitat is in fact intermediate between strictly marine and freshwater. It is generally accepted that members of the order Cladophorales originated and evolved in marine environments. The basal position of Cladophora conchopheria and Wittrockiella lyallii in the Aegagropila clade was interpreted by Hanyuda et al. (2002) as a step by members of the order Cladophorales towards freshwater habitats. Our data suggest that a marine ancestor, presumably similar to Cladophora conchopheria, gave rise to Spongiochrysis hawaiiensis through a gradual reduction of the thallus and by the production of carotenoid pigments. Spongiochrysis hawaiiensis also shows strikingly how similar adaptations to subaerial life have taken place in phylogenetically unrelated lineages of green algae. Most terrestrial green algae belong to the class Trebouxiophyceae (chlorophyte lineage) and the class Klebsormidiophyceae (charophyte lineage). They are characterized by a very simple morphology, i.e. unicellular, sarcinoid (regular packets formed by a small number of cells), uniseriate filamentous or, less frequently, blade-like thalli (Ettl \& Gärtner, 1995; Friedl, 1995). In terms of number of species, however, the unicellular habit is clearly the most widespread. Simplification of the thallus in the colonization of terrestrial habitats seems therefore to be a universal trend in the evolution of green algae. The observation that, in moving to subaerial habitats, a cladophoralean ancestor reduced its thallus to a unicellular organization is simply another example of this phenomenon. It is evident that a unicellular habit must provide special advantages in the terrestrial environment, presumably related to dispersal. Most studies in which algae have been isolated from air samples have shown a preponderance of small unicellular forms (Brown et al., 1964; Rosas et al., 1987; Kristiansen, 1996) and the only investigation on this topic carried out in the Hawaiian Islands has provided similar conclusions (Brown, 1971). Roy-Ocotla \& Carrera (1993) concluded that a spheroidal unicell of about $12 \mu \mathrm{m}$ in diameter is the ideal airborne alga. The morphology of Spongiochrysis hawaiiensis is remarkably close to such a model organism. 
The production of a red-orange pigment is an interesting similarity between Spongiochrysis hawaiiensis and members of the order Trentepohliales. Members of the order Trentepohliales, although present in temperate zones, have their highest diversity in the tropics, where they are often the most common terrestrial chlorophytes (López-Bautista et al., 2002). Representatives of the order Trentepohliales produce large amounts of carotenoid pigments, especially $\beta$-carotene and haematochrome (López-Bautista et al., 2002). The production of carotenoids is stimulated by conditions of strong illumination (Ho et al., 1983; Abe et al., 1998) and it is believed that, when present in large amounts, these pigments act as a protection from photooxidation (Siefermann-Harms, 1987; Abe et al., 1998). As Spongiochrysis hawaiiensis grows in a type of habitat that is also common to many tropical members of the order Trentepohliales (Rindi et al., 2005), it is not surprising to find similar pigments. In fact, due to the similarity in colour and habitat, Spongiochrysis hawaiiensis was originally confused with species of the genus Trentepohlia (the most common genus of the order Trentepohliales in the Hawaiian Islands; Rindi et al., 2005). A detailed characterization of the pigments occurring in Spongiochrysis hawaiiensis, which was not possible in the present study, would be desirable. Evidence is available that in the order Cladophorales/Siphonocladales, the composition of carotenoid pigments may be a better phylogenetic marker than morphological features (Yoshii et al., 2004). Detailed ultrastructural analyses might also be of help in obtaining better insights into the phylogeny of this group. The ultrastructure of the pyrenoid shows considerable variation in the order Cladophorales and the arrangement of the thylakoid bands in Cladophora conchopheria is markedly different from that in most other species of the genus Cladophora (Yang, 1989; Matsuyama et al., 1998). Although no pyrenoids are distinctly observable in Spongiochrysis hawaiiensis, further observations may reveal ultrastructural characters of interest from a phylogenetic point of view.

Finally, the discovery of Spongiochrysis hawaiiensis highlights the urgent need for a better understanding of several aspects of the biology of little-known Pacific habitats. The terrestrial algal flora of the Hawaiian Islands and many other Pacific islands is very poorly known. It is surprising that botanists who have been based in Hawaii have never paid any attention to such a distinctive organism as Spongiochrysis hawaiiensis, especially considering its commonness and abundance. The Hawaiian Archipelago, characterized by high habitat complexity (Mueller-Dombois, 2002), has been already shown to be a biodiversity hotspot for other microbial forms (Donachie et al., 2004). In our opinion, further evolutionary surprises as remarkable as Spongiochrysys hawaiiensis are guaranteed with additional modern systematic surveys.

\section{ACKNOWLEDGEMENTS}

F. R. acknowledges the Higher Education Authority, Ireland, for financial support during the time the study was conducted. A. R.S. thanks the Hawaii Division of Aquatic Resources and the University of Hawaii for financial support. Drs Hans Sluiman (Royal Botanical Gardens, Edinburgh), Jiř́ Neustupa (Charles University, Prague) and Georg Gärtner (University of Innsbruck) provided much useful information and stimulating discussion. Professor Michael Wynne (University of Michigan, Ann Harbour) kindly provided help with bibliographic references.

\section{REFERENCES}

Abe, K., Mihara, H. \& Hirano, M. (1998). Characteristics of growth and carotenoid accumulation of the aerial microalga Trentepohlia aurea in liquid culture. J Mar Biotechnol 6, 53-58.

Bakker, F. T., Olsen, J. L., Stam, W. T. \& van den Hoek, C. (1994). The Cladophora complex (Chlorophyta): new views based on $18 \mathrm{~S}$ rRNA gene sequences. Mol Phylogenet Evol 3, 365-382.

Brown, R. M. (1971). Studies of Hawaiian fresh-water and soil algae. I. The atmospheric dispersal of algae and fern spores across the island of Oahu, Hawaii. In Contributions in Phycology, pp. 175-188. Edited by B. C. Parker \& R. M. Brown. Lawrence, KS: Allen Press.

Brown, R. M., Larson, D. A. \& Bold, H. C. (1964). Airborne algae: their abundance and heterogeneity. Science 143, 583-585.

Chapman, R. L., Buchheim, M. A., Delwiche, C. F. \& 8 other authors (1999). Molecular systematics of the green algae. In Molecular Systematics of Plants II, pp. 508-540. Edited by P. S. Soltis, D. E. Soltis \& J. J. Doyle. Norwell, MA: Kluwer.

Donachie, S. P., Hou, S., Lee, K. S. \& 11 other authors (2004). The Hawaiian archipelago: a microbial diversity hotspot. Microb Ecol 48, 509-520.

Ettl, H. \& Gärtner, G. (1995). Syllabus der bode-, luf- und flechtenalgen. Stuttgart: Gustav Fischer (in German)

Famá, P., Wysor, B., Kooistra, W. H. C. F. \& Zuccarello, G. C. (2002). Molecular phylogeny of the genus Caulerpa (Caulerpales, Chlorophyta) inferred from chloroplast tufA gene. J Phycol 38, 1040-1050.

Fawley, M. W., Fawley, K. P. \& Buchheim, M. A. (2004). Molecular diversity among communities of freshwater microchlorophytes. Microb Ecol 48, 489-499.

Felsenstein, J. (1985). Confidence limits on phylogenies: an approach using the bootstrap. Evolution 29, 783-791.

Friedl, T. (1995). Inferring taxonomic positions and testing genus level assignments in coccoid green lichen algae: a phylogenetic analysis of $18 \mathrm{~S}$ ribosomal RNA sequences from Dictyochloropsis reticulata and from members of the genus Myrmecia (Chlorophyta, Trebouxiophyceae cl. nov.). J Phycol 31, 632-639.

Friedl, T. (1997). The evolution of the green algae. Plant Syst Evol, Suppl 11, 87-101.

Fritsch, F. E. (1907). The subaerial and freshwater algal flora of the Tropics. A phytogeographical and ecological study. Ann Bot 21, 235-275.

Gontcharov, A. A., Marin, B. A. \& Melkonian, M. A. (2003). Molecular phylogeny of conjugating green algae (Zygnemophyceae, Streptophyta) inferred from SSU rDNA sequence comparisons. J Mol Evol 56, 89-104.

Hamby, R. K., Sims, L., Issel, L. \& Zimmer, E. (1988). Direct ribosomal RNA sequencing: optimization of extraction and sequencing methods for work with higher plants. Plant Mol Biol Rep 6, 175-192.

Handa, S., Nakahara, M., Tsubota, H., Deguchi, H. \& Nakano, T. (2003). A new aerial alga, Stichococcus ampulliformis sp. nov., (Trebouxiophyceae, Chlorophyta) from Japan. Phycol Res 51, 203-210. 
Hanyuda, T., Wakana, I., Arai, S., Miyaji, K., Watano, Y. \& Ueda, K. (2002). Phylogenetic relationships within Cladophorales (Ulvophyceae, Chlorophyta) inferred from $18 \mathrm{~S}$ rRNA gene sequences, with special reference to Aegagropila linnaei. J Phycol 38, 564-571.

Henley, W. J., Hironaka, J. L., Guillou, L., Buchheim, M. A., Buchheim, J. A., Fawley, M. W. \& Fawley, K. P. (2004). Phylogenetic analysis of the "Nannochloris-like" algae and diagnoses of Picochlorum oklahomensis gen. et sp. nov. (Trebouxiophyceae, Chlorophyta). Phycologia 43, 641-652.

Hindák, F. (1976). Marvania geminata gen. nov. et sp. nov., a new green alga. Algol Stud 16, 261-270.

Ho, K. K., Tan, K. H. \& Wee, Y. C. (1983). Growth conditions of Trentepohlia odorata (Chlorophyta, Ulotrichales). Phycologia 22, 303-308.

Hoffmann, L. (1989). Algae of terrestrial habitats. Bot Rev 55, 77-105.

Holmgren, P. K., Holmgren, N. H. \& Barnett, L. C. (1990). Index Herbariorum. Part I: The Herbaria of the World. Koenigstein, Germany: Koeltz Scientific Books.

Huelsenbeck, J. P. \& Ronquist, F. (2001). MRBAYES: Bayesian inference of phylogenetic trees. Bioinformatics 17, 754-755.

Kooistra, W. H. C. F., Olsen, J. L., Stam, W. T. \& van den Hoek, C. (1993). Problems relating to species sampling in phylogenetic studies: an example of non-monophyly in Cladophoropsis and Struvea (Siphonocladales, Chlorophyta). Phycologia 32, 419-428.

Krienitz, L., Hegewald, E., Hepperle, D. \& Wolf, A. (2003). The systematics of coccoid green algae: $18 \mathrm{~S}$ rRNA gene sequence data versus morphology. Biologia Bratislava 58, 437-446.

Krienitz, L., Hegewald, E. H., Hepperle, D., Huss, V. A. R., Rohr, T. \& Wolf, M. (2004). Phylogenetic relationship of Chlorella and Parachlorella gen. nov. (Chlorophyta, Trebouxiophyceae). Phycologia 43, 529-542.

Kristiansen, J. (1996). Dispersal of freshwater algae - a review. Hydrobiologia 336, 151-157.

Leliaert, F., Rousseau, F., De Reviers, B. \& Coppejans, E. (2003). Phylogeny of the Cladophorophyceae (Chlorophyta) inferred from partial LSU rRNA gene sequences: is the recognition of a separate order Siphonocladales justified? Eur J Phycol 38, 233-246.

Lewis, L. A. \& McCourt, R. M. (2004). Green algae and the origin of land plants. Am J Bot 91, 1535-1556.

López-Bautista, J. M. \& Chapman, R. L. (2003). Phylogenetic affinities of the Trentepohliales inferred from small-subunit rDNA. Int J Syst Evol Microbiol 53, 2099-2106.

López-Bautista, J. M., Waters, D. A. \& Chapman, R. L. (2002). The Trentepohliales revisited. Constancea 83.1 (http://ucjeps.berkeley. edu/constancea/83/lopez_etal/trentepohliales.html)

Maddison, D. R. \& Maddison, W. P. (2001). MacClade 4: Analysis of phylogeny and character evolution, version 4.03. Sunderland, MA: Sinauer Associates.

Matsuyama, K., Matsuoka, T., Miyaji, K., Tanaka, J. \& Aruga, Y. (1998). Ultrastructure of the pyrenoid in the family Cladophoraceae (Cladophorales, Chlorophyta). J Jpn Bot 73, 279-286.

McCourt, R. M., Karol, K. G., Bell, J., Helm-Bychowski, K. M., Grajewska, A., Wojciechowski, M. F. \& Hoshaw, R. W. (2000). Phylogeny of the conjugating green algae (Zygnemophyceae) based on $r b c$ L sequences. J Phycol 36, 747-758.

Mueller-Dombois, D. (2002). Forest vegetation across the tropical Pacific: a biogeographically complex region with many analogous environments. Plant Ecol 163, 155-176.
Neustupa, J. \& Šejnohová, L. (2003). Marvania aerophytica sp. nov., a new subaerial tropical green alga. Biologia 58, 503-507.

Nienow, J. A. (1996). Ecology of subaerial algae. Nova Hedwigia Beih 112, 537-552.

O'Kelly, C. J., Wysor, B. \& Bellows, W. K. (2004). Gene sequence diversity and the phylogenetic position of algae assigned to the genera Phaeophila and Ochlochaete (Ulvophyceae, Chlorophyta). J Phycol 40, 789-799.

Posada, D. \& Crandall, K. A. (1998). MODELTEST: testing the model of DNA substitution. Bioinformatics 14, 817-818.

Reymond, O. L., Hindák, F. \& Sluiman, H. J. (1986). Morphologie cellulaire et cycle de développement chez l'algue verte Marvania geminata Hindák (1976). Arch Sci Genève 39, 243-255 (in French).

Rindi, F., Mclvor, L. \& Guiry, M. D. (2004). The Prasiolales (Chlorophyta) of Atlantic Europe: an assessment based on morphological, molecular, and ecological data, including the characterization of Rosenvingiella radicans (Kützing) comb. nov. J Phycol 40, 977-997.

Rindi, F., Sherwood, A. R. \& Guiry, M. D. (2005). Taxonomy and distribution of Trentepohlia and Printzina (Trentepohliales, Chlorophyta) in the Hawaiian Islands. Phycologia 44, 270-284.

Rosas, I., Roy-Ocotla, G., Mosiño, P., Baez, A. \& Rivera, L. (1987). Abundance and heterogeneity of algae in the Mexico City atmosphere. Geofis Int 26, 359-373.

Roy-Ocotla, G. \& Carrera, J. (1993). Aeroalgae: responses to some aerobiological questions. Grana 32, 48-56.

Sakai, Y. (1964). The species of Cladophora from Japan and its vicinity. Sci Pap Inst Algol Res Fac Sci Hokkaido Univ 5, 1-104.

Sherwood, A. R. (2004). Bibliographic checklist of the non-marine algae of the Hawaiian Islands. Bishop Mus Occ Pap Series 80, 1-23.

Sherwood, A. R., Garbary, D. J. \& Sheath, R. G. (2000). Assessing the phylogenetic position of the Prasiolales (Chlorophyta) using $r b c \mathrm{~L}$ and $18 \mathrm{~S}$ rRNA gene sequence data. Phycologia 39, 139-146.

Siefermann-Harms, D. (1987). The light-harvesting and protective functions of carotenoids in photosynthetic membranes. Physiol Plant 69, 561-568.

Sluiman, H. J. \& Reymond, O. L. (1987). Cell division in the green microalga Marvania geminata: semi-exogenous autosporogenesis, role of coated pit-microtubule complexes, and systematic significance. Acta Bot Neerl 36, 231-245.

Swofford, D. L. (2000). PAUP ${ }^{*}$ : Phylogenetic analysis using parsimony (* and other methods), version 4. Sunderland, MA: Sinauer Associates.

Tan, I. H., Blomster, J., Hansen, G., Leskinen, E., Maggs, C. A., Mann, D. G., Sluimam, H. J. \& Stanhope, M. J. (1999). Molecular phylogenetic evidence for a reversible morphogenetic switch controlling the gross morphology of two common genera of green seaweeds, Ulva and Enteromorpha. Mol Biol Evol 16, 1011-1018.

Van den Hoek, C., Mann, D. G. \& Jahns, H. M. (1995). Algae - an Introduction to Phycology. Cambridge: Cambridge University Press.

Yang, W. X. (1989). Observations on pyrenoid ultrastructure of Cladophora conchopheria (Charophyceae). Jpn J Phycol 37, 57-59.

Yoshii, Y., Hanyuda, T., Wakana, K., Miyaji, K., Arai, S., Ueda, K. \& Inouye, I. (2004). Carotenoid compositions of Cladophora balls (Aegagropila linnaei) and some members of the Cladophorales (Ulvophyceae, Chlorophyta): their taxonomic and evolutionary implication. J Phycol 40, 1170-1177. 